\title{
Strengthening informal seed systems to enhance food security in Southeast Asia
}

Thomas B. Gill, a* The Pennsylvania State University

Ricky Bates, ${ }^{\mathrm{b}}$ The Pennsylvania State University

Abram Bicksler, ${ }^{c}$ International Sustainable Development Studies Institute

Rick Burnette, ${ }^{\mathrm{d}}$ ECHO Asia Impact Center

Vincent Ricciardi, ${ }^{\mathrm{d}}$ ECHO Asia Impact Center

Laura Yoder,c International Sustainable Development Studies Institute

Submitted September 7, 2012 / Revised November 30, 2012, January 15, 2013 / Accepted January 16, 2013 /

Published online May 29, 2013

Citation: Gill, T. B., Bates, R., Bicksler, A., Burnette, R., Ricciardi, V., \& Yoder, L. (2013). Strengthening informal

seed systems to enhance food security in Southeast Asia. Journal of Agriculture, Food Systems, and Community

Development, 3(3), 139-153. http://dx.doi.org/10.5304/jafscd.2013.033.005

Copyright (C) 2013 by New Leaf Associates, Inc.

\section{Abstract}

In 2011, the number of hungry people in the world

\footnotetext{
a International Programs, College of Agricultural Sciences, The Pennsylvania State University, University Park, Pennsylvania 16802 USA

b Department of Plant Science, The Pennsylvania State University, University Park, Pennsylvania 16802 USA; rmb30@psu.edu

${ }^{\mathrm{c}}$ International Sustainable Development Studies Institute, P.O. Box 222, Prasingh, Chiang Mai 50205, Thailand; abicksler@isdsi.org

d ECHO Asia Impact Center, 270/5 Tung Hotel Road, Soi 6, P.O. Box 64, Chiang Mai 50000, Thailand; rburnette@,echonet.org

* Corresponding author: Thomas B. Gill, +1-814-865-8309, tbg12@psu.edu
}

surpassed one billion for the first time. The majority of these people are largely dependent for their food security upon resource-poor smallholder farmers in developing or emerging economies. These smallholders depend on informal seed systems for $75-90 \%$ of their food crop cultivation. Southeast Asia, one of the world's biodiversity hotspots in the face of rapidly dwindling global genetic diversity, is at the forefront of seed systems issues. This article examines activities undertaken by a collaboration of researchers and local institutions to enhance food security within informal seed systems in Thai and Cambodian rural communities. We employed a two-step model for strengthening food security using a range of participatory activities to first understand and characterize, and secondly strengthen informal seed systems in the target regions. We documented seed 
pathways, histories, and storage as well as gender roles in each community. Informal seed systems were strengthened through identifying potential species for commercialization, addressing technological barriers to seed analysis, and conducting seed fairs and seed banking. These activities not only strengthened informal seed systems, but also significantly enhanced all four pillars of food security in the study communities. Recommendations for future informal seed systems and food security research include extending research into more communities and countries, focusing on the potential for enhancing formal seed systems, and examining the possibilities for synergies with food sovereignty approaches.

\section{Keywords}

appropriate technology, biodiversity, Cambodia, food security, hunger, participatory methods, seed systems, Thailand

\section{Introduction}

In 2011, the number of hungry people in the world surpassed one billion for the first time (Food and Agriculture Organization of the United Nations [FAO], 2011). Disasters such as the famine in the Horn of Africa and a mega-typhoon scything through the Philippines, in conjunction with rapidly rising food prices worldwide, have further reduced food security for millions of people. Despite a declining trend in the proportion of hungry people in the world in the last 30 years of the $20^{\text {th }}$ century, since 2004 there has been a reversal of this trend (FAO, 2011). With the world's population forecast to rise to 9 billion by 2050, Malthusian speculation has once again emerged with concerns that the number of hungry and malnourished people will continue to rise and outpace food production increases, resulting in a food insecure world.

Food security was first defined at the 1974 World Food Summit as "availability at all times of adequate world food supplies of basic foodstuffs to sustain a steady expansion of food consumption and to offset fluctuations in production and prices" (United Nations, 2003, "Official concepts of food security," para. 2), reflecting the main supply-side concerns at the time in the context of repeated famines, hunger, and food crises around the world. Since then, the concept has been re-defined numerous times, and generally accepted definitions of food security have adopted a threefold axis of availability, accessibility, and utilization of food (FAO, 2008). More recently, concerns about the stability of the food system and its relation to the environment have also been incorporated. Despite this concept being present for several decades, food security has taken a sideline until the past few years to other critical global concerns, such as health, education, and the environment. All has changed in the past five years. Food security concerns rose rapidly to the forefront of the global agenda beginning with the food price crisis of 2007-2008. Food riots from Haiti to Mozambique brought the realization that the world hunger problem had not yet been solved. At the 2009 L'Aquila summit, the G8 nations acknowledged the need to tackle food insecurity head on, and pledged $\$ 22 \mathrm{bn}$ to set up the Global Agriculture and Food Security Program (GAFSP), administered jointly by the World Bank, International Monetary Fund, and G8 governments (United States Treasury, 2011).

Renewed emphasis thus is now being placed on addressing food security at its roots - in regions and locales where undernourishment is king and many households live daily on the edge. Arguably the most important focus of present-day food security concerns is resource-poor smallholder farmers in developing or emerging economies. The vast majority of the world's one billion undernourished people resides in Asia or subSaharan Africa and depends daily on small farm output for their livelihood and/or their food. This farm output is dependent upon many inputs, of which seed is one of the most critical. Without available or accessible seed, many households in developing nations are exposed to the potential of becoming food insecure.

In much of the developing world, informal seed systems remain the prevailing source of seed for smallholder farmers (Seboka \& Deressa, 1999; Thiele, 1999). Informal seed systems are characterized by multiple components, including (1) farmer self-saved seed of indigenous annual and perennial vegetable crops, (2) informal seed markets, (3) seed 
networks and "germplasm gatekeepers," (4) informal seed storage mechanisms, and (5) the conservation of the knowledge base surrounding the local system. Such systems are termed informal because they are (1) farmer organized and managed, (2) flexible and dynamic, (3) indigenous to a community or set of communities, (4) local or regional in scope and scale, and (5) typically undocumented (Sperling, 2008).

The informal seed system contrasts with the formal seed system, which involves governmental, institutional, or private control of the whole gamut of seed activities, including but not limited to breeding, multiplication, processing, and storage. Such formal systems are typically vertically organized with specific structures in place for production and distribution of seed and operate on generally strict and similar principles across the globe (Almekinders, Louwaars \& de Bruijn, 1994). These formal systems are the source of modern varieties and certified seed (Sperling \& McGuire, 2010), usually developed through modern breeding technologies and often tested on research farms.

The landscape in many parts of rural southeast Asia is dominated by resource-poor smallholders, who operate complex, biodiverse farming systems. Informal seed systems central to such farming systems are critical to enhancing $21^{\text {st }}$ century global food security for several interconnected reasons (Tscharntke, Clough, Wanger, Jackson, Motzke, Perfecto, Vandermeer, \& Whitbread, 2012). First, seed sourced from informal systems by resourcepoor smallholders in developing countries, such as those in southeast Asia, is estimated to account for $75 \%$ to $90 \%$ of all food crops cultivated (Almekinders et al., 1994; Sperling \& McGuire, 2010). Although some farmers may be able to purchase seed and access the formal seed system for some commonly cultivated food crops, such as rice, the informal seed system is the primary and often sole source of the majority of foods in these smallholder communities.

Secondly, informal seed systems are critical for the production of a diversity of foods to ensure dietary diversity in smallholder communities. Many crop species integral to the informal seed system provide valuable macro- and micronutrients to the communities in which they are grown and con- sumed. In particular, informal seed systems are often the sole source of neglected and underutilized species (NUS), which are critical for providing the vast majority of essential nutrients to smallholder communities (Mayes, Massawe, Alderson, Roberts, Azam-Ali, \& Hermann, 2012). There is significant potential to extend the nutritional benefits of NUS in particular to regional and global levels to assuage the growing scourge of hidden hunger and the increasing homogenization of the global food base.

Thirdly, informal seed systems are central to the conservation of biodiversity in smallholder production systems (Badstue, Bellon, Berthaud, Juárez, Rosas, Solano, \& Ramírez, 2006) and, hence, the ecological landscape of Southeast Asia. Renowned Russian botanist Nikolay Vavilov included a region of Asia stretching from the Indian subcontinent through Southeast Asia as a "key global center of origin" for food crops (Nabhan, 2009). More than 170 crop species originate in this geographic swath. The Southeast Asian peninsula has since been recognized as a hotspot of biodiversity (Myers, Mittermeier, Mittermeier, da Fonseca, \& Kent, 2000). In Southeast Asia alone there are an estimated 1,500 to 2,000 plant species incorporated into the food system (Engle \& Faustino, 2007). Many of these vegetables are not widely known and could be classified as NUS, often overlooked during inventories, particularly if the species are foraged from the wild versus tended in garden plots or farmers' fields. The informal seed system in this region is critical to maintaining biodiverse agroecologies as it is the main source of diverse germplasm.

Furthermore, informal seed systems broaden the genetic base of production with multiple crop species and varieties adapted to specific production systems and microclimates. By preserving in situ locally adapted varieties, saved through the informal seed system and cultivated in biodiverse agroecologies, smallholder communities are able to reduce risk in their agricultural systems (Jackson, Pascual \& Hodgkin, 2007; Thrupp, 2000). Risks may involve ongoing environmental pressures facing smallholders on a daily basis, including pest and disease pressure, low soil fertility, and severe weather conditions. Meanwhile, the provision of 
locally well-adapted germplasm also provides these communities with greater resilience in the face of significant events, including climate change, natural disasters, and political instability, pressures all too familiar in Southeast Asia. Strengthening informal seed systems that revolve around a broad genetic base thus provides an alternative paradigm to the increasing corporate control and monopolization of the global formal seed system that is resulting in an increasingly rapid reduction in global seed biodiversity (Schanbacher, 2010).

Finally, the rich diversity of indigenous germplasm in informal seed systems represents a valuable resource for the development and improvement of crop species locally, regionally, and globally. Many of the species that are preserved in informal seed systems may have significant untapped potential for commercialization and diversification of diets, which could lead to improved nutrition globally. Although local vegetable varieties are currently grown mostly for home consumption, over the past decade they have been increasingly sold in urban markets in Southeast Asia. The high diversity of ethnic groups within a small region has produced extraordinary diversity in indigenous vegetables, as different groups favor specific culinary and agronomic qualities.

Despite this critical importance of informal seed systems to smallholder communities, little is known or documented about how households in these agroecosystems select, conserve, and exchange their biodiverse germplasm resources. This project sought to address this issue and strengthen these informal seed systems in rural Southeast Asia using methodologies that could enhance food security. The two main objectives of this project were to:
1. Understand and characterize informal seed systems, including species, pathways, and "germplasm gatekeepers" for indigenous annual and perennial vegetable crops important to Northern Thailand hilltribe communities, and Cambodian Khmer farmers.

2. Facilitate the exchange, preservation, and dissemination of important genetic resources identified through participatory methodologies employed under objective 1 in order to strengthen the informal seed systems in each community.

\section{Study Areas}

The three study communities for this project were located in rural areas in Thailand and Cambodia. Two of the study communities were located near the Myanmar border of northern Thailand, with the third located in the Svay Rieng Province of southeast Cambodia, adjacent to the border of Vietnam (figure 1). The two northern Thai study sites, in Chiang Dao (Chiang Mai Province) and

\section{Figure 1. Locations of the Study Communities in Northern Thailand and} Southeastern Cambodia. Map scale 1:18,500,000.

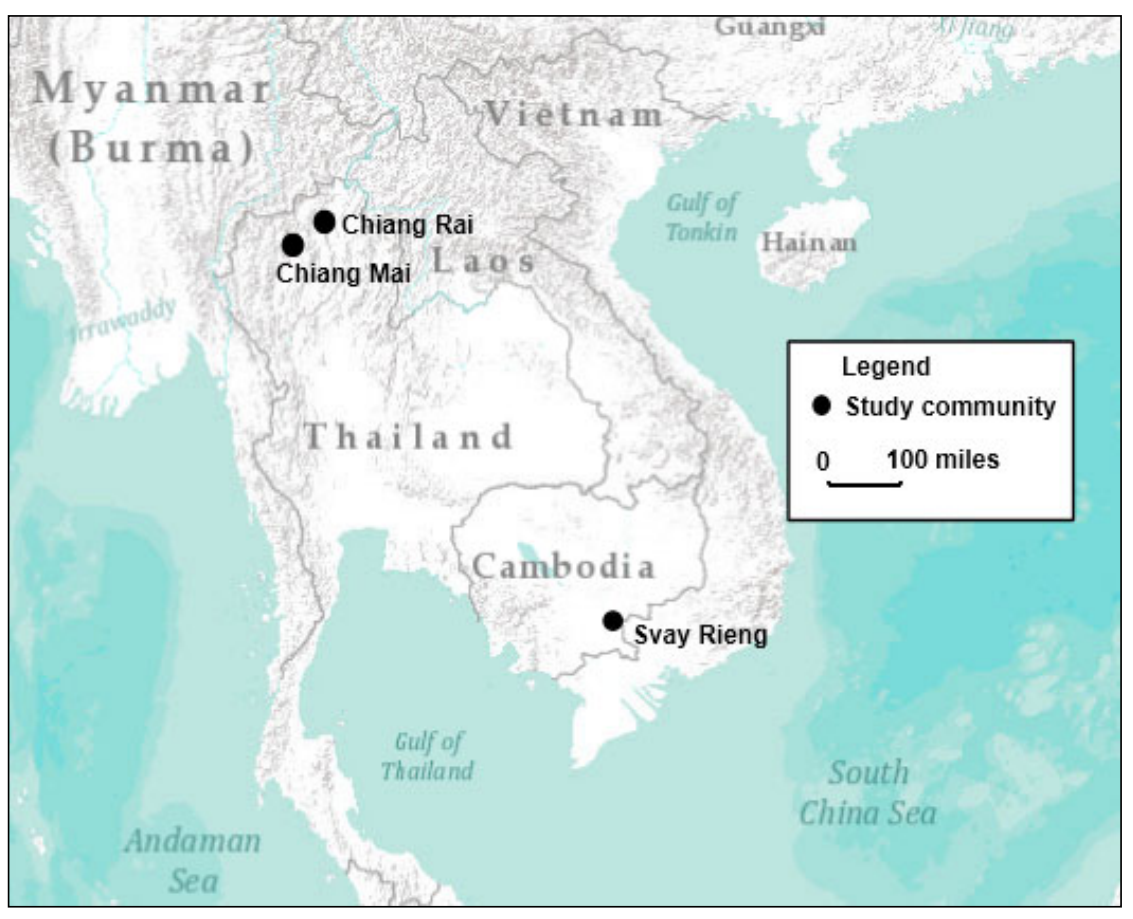

Map produced courtesy of Arc Explorer Online, www.esri.com 
Mae Yao (Chiang Rai Province), are composed of clusters of upland communities and ethnic groups. The Chiang Dao study community clusters are largely composed of ethnic Palaung with a minority of Lahu residents. The ethnic composition of the Mae Yao community clusters is somewhat more diverse, including three distinct Lahu groups (Black, Yellow, and Red) as well as the Akha ethnic group. In contrast, the population of the Svay Rieng study community clusters in Cambodia is entirely Khmer. All three communities fall in the broad geographic swath identified by Vavilov as being rich in biodiversity, and the Thai-Cambodian contrast was chosen to compare communities with different ethnic backgrounds and who are dealing with different agroecologies.

Although language and religious differences separate the Thai hilltribe groups, they share similar recent histories and livelihoods. All the communities in the two Thai sites were established by migrants from Myanmar, with most of the recent migration having taken place between the early 1960s and mid-1980s. In comparison, the Khmer survey collaborators in the Svay Rieng area are native to a region that is still recovering from the Vietnam War and subsequent Khmer Rouge regime (1975-79). Average annual income for households in the Thai communities is considerably lower than the Thai national average of 141,480 baht (US\$4,716), while income in the Svay Rieng community clusters is only approximately onequarter of both an average household in Cambodia (US\$931) and households in the two Thai community clusters (table 1).
Food insecurity remains a risk for many in all three study sites. Childhood malnutrition is prevalent, especially in the Khmer communities. In Thailand, with both community clusters located on public land (national park and reserve forest), there is no formal land ownership or secure land tenure. Although many residents seek outside, supplemental employment as wage laborers, agriculture remains the main local livelihood, centered around complex biodiverse farming systems. These systems are centered around rice production for food, supplemented by a variety of annual and perennial vegetables grown primarily in mixed home gardens and used abundantly, both raw and cooked, in local dishes. Crops that are cultivated strictly for market sale are few, but do include maize and some legumes. Farmers in Mae Yao (Chiang Rai) have limited access to rainfed paddy (approximately 0.64 ha per family), whereas those in Chiang Dao lack access to such paddy environment. However, the majority of households in both Thai study communities tend home gardens, particularly during the rainy season, and gather wild vegetables from the forest. In general, the residents of Svay Rieng have limited access to farmland, mainly growing irrigated paddy rice during the rainy season. In this region, household food production is generally at the subsistence level, with reliance on small home gardens. Compared to northern Thailand, there is much less forest cover in southeast Cambodia, resulting in limited access to wild foods.

In all three communities, the agricultural system is distinctly gendered through both the different spatial domains of men and women and the

\section{Table 1. Key Characteristics of Study Community Clusters}

\begin{tabular}{lccc}
\hline Characteristic & $\begin{array}{c}\text { Chiang Dao District, } \\
\text { Chiang Mai Province } \\
\text { (Thailand) }\end{array}$ & $\begin{array}{c}\text { Mae Yao District, } \\
\text { Chiang Rai Province } \\
\text { (Thailand) }\end{array}$ & $\begin{array}{c}\text { Svay Rieng Province } \\
\text { (Cambodia) }\end{array}$ \\
\hline Ethnic group & Palaung, Lahu & Lahu, Akha & Khmer \\
Historical ties & Myanmar & Myanmar & Cambodia/Vietnam \\
Average (mean) annual income (US\$) & 995 & 827 & 220 \\
Population of province (million) & 1.68 & 1.19 & 0.56 \\
Average farm size (ha/acres) & $3.0 / 7.4$ & $2.0 / 4.9$ & $1.2 / 3.0$ \\
Environment & Tropical highland & Tropical highland & Tropical lowland \\
\hline
\end{tabular}

Sources: Kingdom of Cambodia, 2009; Government of the Kingdom of Thailand, 2011, 2012. 
gendered division of knowledge in these communities. Women keep home gardens - small, multipurpose gardens adjacent to a dwelling — with crops for household consumption, a common piece of the agricultural system in Southeast Asia (Gajaseni \& Gajaseni, 1999; Kehlenbeck \& Maass, 2004; Srithi, Trisonthi, Wangpakapattanawong, Srisanga, \& Balslev, 2012). This allows women to have a hand in providing for their households while remaining in the vicinity of their homestead for other female-assigned activities, such as childcare, cleaning, and washing clothes. Women's involvement in home gardens ensures their role as gatekeepers of germplasm and of knowledge about indigenous vegetable species for household use. Women's use of home gardens is therefore critical in conserving biocultural diversity and ensuring the nutritional quality of household diets (Kumar \& Nair, 2004). Women's day-to-day handling of a variety of locally important species also facilitates their familiarity with a range of crops about which they know significantly more than men. Men, meanwhile, invest their time in learning about other important household enterprises that fall within their typical domains. The spatial domains of men are typically away from the home, gathering forest products (in Thailand only), keeping fields, hunting, and dealing with animals such as pigs, fish, and chickens. In our observation, men do not have as keen an eye on seed selection, separation, and storage from the informal system as do the women.

\section{Methods}

Methodologies undertaken involved a two-step process of (1) understanding and characterizing the informal seed systems, and (2) strengthening these systems.

\section{Understanding and Characterizing Informal Seed Systems}

We conducted a variety of participatory activities to facilitate understanding and knowledge of the informal seed systems not only by researchers but also by households in the study communities. The first of these activities was to conduct semistructured household and individual interviews in the three study communities. The research team met with community leaders and organized a sampling framework based on wealth stratification of each community to ensure that sampled households spanned the range of socioeconomic strata. We selected four villages in each of three village clusters (communities). A total of 171 (40 in Chiang Dao, 30 in Chiang Rai, and 101 in Svay Rieng) semistructured, observation-based interviews with $10 \%$ of the households in each community were conducted. Interviews were conducted in each home and garden/farm to permit observation of actual seed-saving and storage practices. Interviews covered topics such as novel and annual seed acquisition, seed trade pathways, and seed selection and saving practices.

Secondly, we conducted focus groups with male and female representatives from several households in each community and utilized participatory resource mapping, shared histories, and gender roles exercises. For the mapping exercises, the groups drew their community location, identified available natural, social, and economic resources, and illustrated the location and importance of these resources. For the shared histories exercises, groups constructed a timeline of their recent history, identifying particular events that impacted their seed system in terms of seed selection, exchange pathways, and storage. For the gender roles exercises, participants in each community were split into two groups (one male and one female) and were asked to identify the gender responsible (male, female or both) for each of 12 different tasks associated with household participation in selected activities related to seed systems and vegetable production.

Finally, researchers compiled a set of large picture cards of 77 annual and perennial vegetables in the region, based on researcher experience and knowledge of the target communities. Each card included a color photograph of the plant, its edible vegetable parts and/or seeds, which enabled villagers to recognize the species. These cards were used in both individual interviews and focus-group discussions as a common visual reference point to obtain the crop names in local languages and to discuss the presence and use of those vegetables in each community (Bicksler, Bates, Burnette, Gill, Meitzner Yoder, Ricciardi \& Srigiofun, 2012). 


\section{Strengthening Informal Seed Systems}

\section{Identify species of potential commercialization}

Participants involved in the card sorts to understand and characterize the informal seed systems in their communities were then invited to participate in a follow-up activity to (1) identify species that were not included in the card sorts, and (2) help researchers generate additional lists of important, yet often (still) underutilized indigenous species. Participants gave species identified a score to rank their utilization, whereby $0=$ common, $1=$ uncommon, and $2=$ rare. Participants were also asked to identify whether a species was important or unimportant to their seed system in terms of household diet or a potentially marketable crop. This activity was conducted to uncover which species had the greatest untapped potential for future crop improvement and commercialization for the target communities.

\section{Address technological barriers to seed analysis}

In-situ experimentation involved seed viability (germination and vigor) experiments using locally available species, collected through donations from local households during the card sorts and structured interview times. We constructed germination chambers at the nongovernmental organization ECHO's (Educational Concerns for Hunger Organization) seed bank and in each community, made out of locally available, low-cost materials. We then conducted these experiments both at the ECHO seed bank and in the village to procure real-time vigor and germination data while conducting the household interviews and focus groups, and to train local people in appropriate technology usage and stimulate interest in simple research methodologies within the communities.

\section{Conduct seed fairs and seed banking}

Three seed fair events were held (one in each province) in early 2011. The first was held in Pang Daeng Nawk community in the Chiang Dao District (Chiang Mai Province), the second in Mae Yao District (Chiang Rai Province), and the third in Svay Rieng Province, Cambodia. The seed fair events created opportunities for farmers to learn about seed saving through the teaching of local nongovernmental organizations and to share knowledge and seeds, the majority of which were unavailable through the formal seed system. We held brief seed-saving training sessions as part of each fair in which we used a specially designed flip chart highlighting different seed species to help increase farmer awareness and knowledge.

In order to increase the availability of informal seed system germplasm and to extend the reach of this germplasm into new communities, we encouraged project participants during interviews, focus groups, and seed fairs to donate a small portion of their available germplasm for conservation at the ECHO Asia Regional Impact Center's seed bank at the Upland Holistic Development Project (UHDP) in Mae Ai, Thailand. ECHO's seed bank operates as a germplasm repository with currently more than 400 master accessions of locally important species, with the goals of increasing the availability of appropriate seeds of select regionally important crops among development workers and communities, encouraging regional seed saving and sharing.

In addition, we conducted training of selected Thai or Cambodian seed germplasm gatekeepers from the study communities about seed systems and in particular about community seed banking. One Thai national was trained at the ECHO seed bank in Mae Ai, Thailand, and also at the ECHO headquarters in Fort Myers, Florida, in low-cost and appropriate technology seed system activities, including seed selection, cleaning, inventory maintenance, germination and vigor trials, storage, and grow-out for multiplication.

\section{Results}

\section{Characterized Seed Systems}

Household interviews and participatory methodologies revealed that seed saving is far more frequent and important among poor households than wealthier households, who have greater access to commercial seed. Purchased seed carries greater prestige than home-saved seed, and thus wealthier households prefer and seek to be more closely connected with the formal seed system. Additionally, poor villagers tend to trade with those of similar socio-economic standing, rather than approaching wealthier village members to trade or 
borrow seed. In all cases, vegetable seeds are reportedly traded freely without expectation of return in terms of cash, seed, or produce. In terms of seed trading pathways, the Thai communities in particular confined their trading to ethnic lines, with just a few reported cases of seed being traded across ethno-linguistic lines. These examples serve to highlight that the quality of social ties within and between these communities is critical in determining the dynamics of mutual seed exchange (McGuire, 2008).

Seed histories revealed that villagers who resettled recently (in the past 30 to 50 years) attempted to carry seeds of their culturally most important crops, but lost several of these species as they fled through conflict. In northern Thailand, many of these resettled refugees came from or through civil unrest in China or Burma, while in Cambodia, many communities were ravaged for several years under the brutal Khmer Rouge regime.

In terms of seed storage, 77 different seed species were identified and analyzed across the three study communities. These were species that were being collected, prepared, and stored at the time of the data collection. Sun drying was the preferred method of preparing seeds for storage (41 species), followed by drying on the plant (29 species), and fire drying (7 species). Sun drying is thought to be the most common method due to the combination of ease of use and ability to quickly bring seeds inside the home if rain comes. Plastic bags were the most common storage vessel, and storage above the fire in the home was the most common storage location (table 2). It is assumed that plastic bags are used because they are readily available, inexpensive, and can be made water-tight to preserve seed viability. Storage above the fire was preferred by many as a place to prevent pest infestation, because the smoke and heat potentially create inhospitable environments for stored seed pests. The two most common combinations of storage vessel and location were seeds kept in plastic bags hung on walls and open seed clusters stored above the household fire (13 species for both methods).

Gender analysis conducted in all three village clusters revealed women's dominant role in the informal seed system. There were no activities in the informal seed system identified by both men and women as ones that were exclusively performed by men. On the other hand, there were many activities identified as exclusively performed by women. Figure 2 shows the breakdown of individual seed system activities for each community, with results aggregated from men's and women's focus-group responses. Activities such as planting, selecting, cleaning, and drying the seeds were typically in the female domain, giving women exclusive access to seeds at the sowing and postharvest stages. Meanwhile, activities such as weeding and harvesting, which required a lot of manual labor, typically were performed by both men and women. Both men and women were active in the sourcing and selling of seeds, while

Table 2. Storage Vessels and Locations for 77 Seed Species, Aggregated Across All Three Communities

\begin{tabular}{lccccc}
\hline Storage Vessel & \multicolumn{5}{c}{ Storage location } \\
\hline & Above Fire & Hung on Wall & $\begin{array}{c}\text { On or In Cabinet } \\
\text { in Kitchen }\end{array}$ & Outside House & Total \\
\cline { 2 - 6 } Plastic bag & 7 & 13 & 3 & 0 & 23 \\
Open seed cluster & 13 & 4 & 1 & 1 & 19 \\
Cloth bag & 9 & 5 & 2 & 0 & 16 \\
Paper bag & 1 & 2 & 4 & 0 & 7 \\
Plastic netting & 5 & 0 & 1 & 0 & 6 \\
Plastic bottle & 0 & 2 & 1 & 0 & 3 \\
In basket & 0 & 0 & 0 & 2 & 2 \\
Glass bottle & 0 & 0 & 1 & 0 & 1 \\
Total & $\mathbf{3 5}$ & $\mathbf{2 6}$ & $\mathbf{1 3}$ & $\mathbf{3}$ & $\mathbf{7 7}$ \\
\hline
\end{tabular}


Figure 2. Gender Roles in the Informal Seed System as Identified by Focus Group Participants in the Three Study Communities

(1) Chiang Mai (Thailand)

\begin{tabular}{|c|c|c|c|c|}
\hline & & $\begin{array}{l}\text { Weeding } \\
\text { Harvesting } \\
\text { Selling } \\
\text { Commercial purchasing } \\
\text { Storing }\end{array}$ & Local sourcing & $\begin{array}{l}\text { Planting decisions } \\
\text { Planting } \\
\text { Selecting } \\
\text { Drying } \\
\text { Preparing food }\end{array}$ \\
\hline$L$ & $\downarrow$ & 1 & 1 & 1 \\
\hline Male & $\begin{array}{c}\text { Male/ } \\
\text { Both }\end{array}$ & Both & $\begin{array}{c}\text { Female/ } \\
\text { Both }\end{array}$ & Female \\
\hline
\end{tabular}

(2) Chiang Rai (Thailand)

\begin{tabular}{|c|c|c|c|c|}
\hline & & $\begin{array}{l}\text { Weeding } \\
\text { Harvesting } \\
\text { Commercial purchasing } \\
\text { Storing }\end{array}$ & $\begin{array}{l}\text { Selling } \\
\text { Preparing food }\end{array}$ & $\begin{array}{l}\text { Planting } \\
\text { Selecting } \\
\text { Cleaning } \\
\text { Drying } \\
\text { Local sourcing }\end{array}$ \\
\hline | & $\mid$ & 1 & 1 & 1 \\
\hline Male & $\begin{array}{l}\text { Male/ } \\
\text { Both }\end{array}$ & Both & $\begin{array}{c}\text { Female/ } \\
\text { Both }\end{array}$ & Female \\
\hline
\end{tabular}

(3) Svay Rieng (Cambodia)

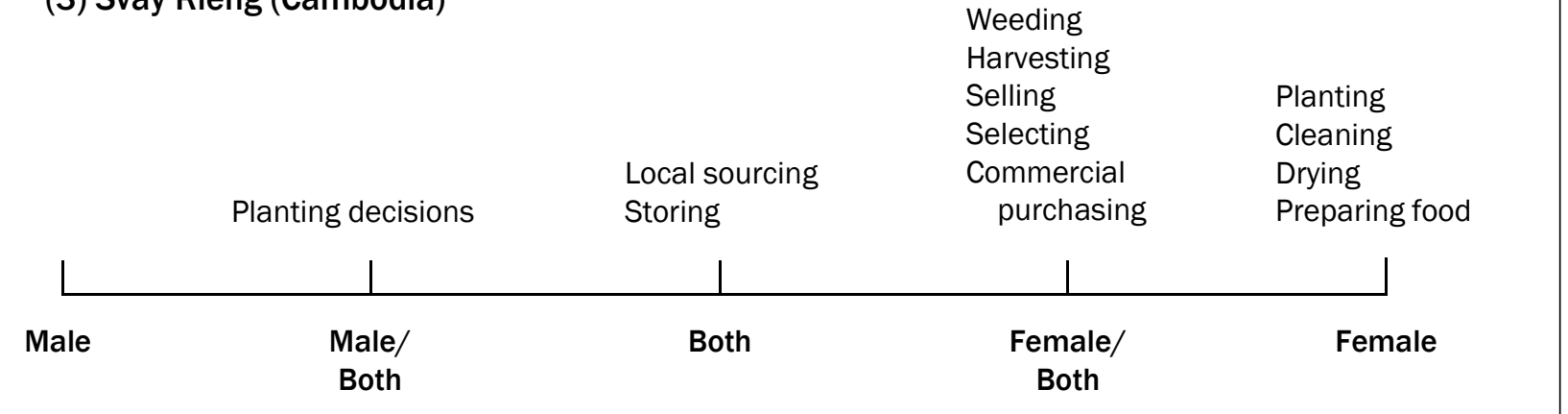

the only activity in all three village clusters that fell more under the male domain was decisions about planting in Svay Rieng, Cambodia.

\section{Strengthened Informal Seed Systems}

\section{Identify species of potential commercialization}

Overall, 23 species were identified that were classi- fied by community members and researchers as important foods, yet that are uncommonly or rarely cultivated or collected. Fifteen of these species are perennial, while eight are cultivated as annuals. Much of the robust diversity present within the food systems of these study communities is due to perennial species used as vegetables. Table 3 provides a partial list of the most important under- 
Table 3. Partial List of Underutilized but Regionally Important Perennial Species Often Consumed as Vegetables in Study Communities

\begin{tabular}{lllll}
\hline Family & Scientific Name & Common Name & Thai Name (ภาษาไทย) & Edible Portion \\
\hline Araliaceae & Trevesia palmata & snowflake tree & tang luang / ต้างหลวง & Shoots, flowers \\
Arecacea & Caryota mitis & fish tail palm & tao rang daeng / เต่าร้างแดง & Inner core (heart) \\
Asclepiadaceae & Gymnema inodorum & chiang daa & chiang daa / เชียงดา & Shoots \\
Bignoniaceae & Oroxylum indicum & Indian trumpet & pheka / เพกา & Flowers, pods \\
Fabaceae & Acacia concinna & shikakai & sompoi / ส้มป่อย & Shoots, flowers, pods \\
Moraceae & Ficus racemosa & cluster fig & madeua kliang / มะเดื่อเกลี่ยง & Leaf shoots \\
Verbenaceae & Clerodendrum & clerodendrum & nang yaem pa / นางแย้มป่า & Leaf shoots \\
\hline
\end{tabular}

utilized perennial species identified in these study communities. Although perennial plants often contribute to family nutrition in significant ways, they are sometimes overlooked during inventories of underutilized indigenous vegetables. This is particularly true if the species are foraged from the wild, versus tended in garden plots or farmers' fields. Perennial plants are also critical to the sustainable management of these biodiverse agroecosystems, as they can maintain ground cover for longer periods of time to reduce soil degradation.

\section{Address technological barriers to seed analysis}

Optimum conditions for seed storage include low temperature and low relative humidity (Rao, Hanson, Dulloo, Ghosh, Nowell, \& Larinde, 2006). However, providing such optimum conditions is particularly difficult to achieve in the hot, humid environment of Southeast Asia.

Seed germination rates were therefore not as high as would be expected from seed in the formal sector. It is generally accepted that the shorter number of days to $50 \%$ germination, the better the chance of seedling survival. So, although Cambodian seeds generally had a lower viability than the other two village clusters, the seeds that did germinate may in fact exhibit greater vigor because of the lower time to $50 \%$ germination (table 4 ).

Meanwhile, across village clusters, seeds in the Fabaceae (bean) family exhibited the greatest viability $(70.8 \%)$, and seeds in the Solanaceae (tomatoes, eggplant, pepper) family exhibited the lowest viability $(21.5 \%)$. The great spread in farmer-saved seed viability across families may be due to inhibi- tory mechanisms in seeds from different seed families or an inherent difficulty in maintaining seed viability for particular seed families in specific locations.

To address these challenges of vigor and germination, we established low-cost germination chambers constructed from locally available materials in each community as well as the ECHO Asia seed bank. During the construction of these chambers, several people from each community were trained in the building and use of these germination chambers for seed germination and vigor testing. We encouraged these people to train others in their communities in order to build capacity for in situ testing of informally saved seed by and for local people.

\section{Conduct seed fairs and seed banking}

Farmers left the seed fairs with enhanced food security because of their increased access to a wider variety of germplasm through seed-swapping; most who attended these fairs left with crop species or varieties that they had not previously cultivated, even though farmers attending the seed fair events

Table 4. Seed Germination and Vigor Results for Donated Seed Species by Study Community

\begin{tabular}{lcc}
\hline Community & $\begin{array}{c}\text { Seed } \\
\text { germination } \\
(\%)\end{array}$ & $\begin{array}{c}\text { Seed vigor } \\
\text { (days to 50\% } \\
\text { germination) }\end{array}$ \\
\hline Chiang Mai & 54.4 & 5.5 \\
Chiang Rai & 64.3 & 6.1 \\
Svay Rieng & 44.2 & 5.3 \\
\hline
\end{tabular}


lived geographically close to one another. In all, more than 150 people participated from nearby communities, and post-swap surveys indicated that on average, each participant both gave and received five packets of seed, with a total of more than 700 packets of seeds exchanged across the three study communities.

Eighty different accessions were donated to the ECHO Asia seed bank during household interviews and seed fair events. The majority of these accessions were from the Thai communities; only 22 distinct seed species were donated by the Cambodian community. Once transferred to the ECHO seed bank, this germplasm was screened for potential on-farm grow-out for seed multiplication and further evaluation and for potential distribution to and promotion among communities across the Southeast Asia region. Those who receive plant material from the ECHO seed bank are encouraged to offer feedback on the performance of each crop under their particular growing conditions. Thus incorporating new accessions into the seed bank enhanced the possibility of extending the benefits of these species to new regions.

\section{Discussion and Future Research Directions: Enhancing Food Security Through Strengthening Informal Seed Systems}

This model of enhancing food security through a variety of activities to strengthen informal seed systems was both comprehensive and effective. The informal seed systems in all three community clusters are now better understood, and informal seed systems strengthened to ensure enhanced local and regional food security. Project activities either directly or potentially strengthened all four pillars of food security in the study communities. First, and probably most effectively, availability of food was increased in each community through activities that sought to expand the reach of germplasm into new households and communities. Activities undertaken to understand and characterize the informal seed system led to increased local awareness and knowledge of the foods (many underutilized) available to communities, and affirmed the value of their diverse germplasm resource base to provide enough food year-round. Hands-on training and in situ experimentation increased local knowledge of how to secure sufficient, high quality germplasm for subsequent growing seasons, thus enhancing the available food sources for future years. Seed fairs improved food availability by promoting seed and knowledge exchange among diverse households, thereby increasing available options of foods to cultivate at the household level. Regional seed banking made possible effective storage, evaluation, and future dissemination of a wide range of available food sources for local communities.

Secondly, access to food was enhanced through a variety of approaches during the project. The most notable of these was through the erosion of intra- and intercommunity barriers to seed access. Intracommunity barriers were reduced primarily using participatory methods, such as resource mapping and the use of focus groups with both male and female participants, which deliberately included women as equal partners in seed systems in the study communities. Such inclusive approaches served to initiate opportunities for pancommunity access to diverse germplasm sources. Intercommunity barriers were especially broken down through seed fair events, which served to develop and enhance networks and market opportunities among diverse ethnic and socioeconomic groups within a geographic area for increased access to diverse crop species and varieties.

Thirdly, utilization of food was potentially improved through activities that strengthened understanding of gender roles and the availability of underutilized species. Women were identified as being able to source a more diverse food base for household meals than men, making them the critical players in enhancing food security through improved food utilization. The identification of multiple species that participants highlighted as key food crops, yet uncommonly or rarely cultivated, served to strengthen the knowledge base of communities on their agrobiodiverse systems and the need to continue to conserve these critically important species.

The final pillar of food security — increased stability of food systems — was also potentially enhanced through project activities. The promotion of underutilized species increased the value attributed to agrobiodiverse systems. This is 
critically important in strengthening the resilience of these systems to shocks such as climate change, as these systems are well adapted to the ecosystems in which they are found and more closely resemble the natural ecosystem structure and functioning than monoculture systems. Increasing household dependence on a wide range of locally adapted species therefore improves the ability of these communities to withstand potentially diverse impacts from external shocks. In addition, the exchange of knowledge among households and communities through the use of participatory methods - particularly the seed fairs - encouraged households to continue to seek ways to adopt diverse livelihood strategies to minimize system risk, seek symbiotic crop-crop and crop-animal relationships, and increase market opportunities and dietary diversity. Furthermore, the sharing of germplasm via seed-swapping at seed fair events encouraged crop diversification, which in turn encouraged households to increase the biodiversity of their rural environments and their provision of ecosystems services, such as enhanced soil fertility, and water, pest, and disease management.

In order to facilitate country-led growth, there is a need to expand this research and extend activities for strengthening informal seed systems into other communities and countries. This scaleup is critical to enhancing food security, preserving biodiversity, and facilitating the sustainable development of these rural agroecosystems. Following the completion of the project, the two Thai community clusters have benefited more than the Khmer cluster due to their proximity to the ECHO Asia Regional Impact Center, which has been able to continue some post-project activities within these communities. Efforts have also been made to expand activities; for example, in early $2011 \mathrm{ECHO}$ Asia seed-bank staff began training community leaders through regional development projects in essential seed-banking practices, including two groups in Myanmar. For maximum impact, this methodological approach to strengthening informal seed systems should continue to be extended into other regions that have high biodiversity, yet are faced with the burdens of hunger and malnutrition. Such regions include not only other parts of South and Southeast Asia, such as Bangladesh,
Laos, and Vietnam, but also many other lowincome regions of the tropics.

One important region with significant potential for work in strengthening informal seed systems is sub-Saharan Africa, where renewed emphasis is being placed on transforming the whole seed sector under calls for a new "uniquely African" Green Revolution (Annan, 2004). The model presented here could complement critical ongoing work, such as AGRA's Programme for Africa's Seed Systems (PASS), by providing additional options for African smallholders to enhance food security (Scoones \& Thompson, 2011). Indeed, the development of stronger informal seed systems might be a way in which formal seed systems (such as those at the focus of PASS efforts) could also be strengthened. An informal seed system that incorporates the generation of higher quality germplasm, increased gender equality and empowerment in managing seed, and increased knowledge of seed system best practices (sourcing, field use, and storage) would result in reduction of losses to the system through poor yields and post-harvest loss, and increased household incomes through increased and higher quality produce to market. These increased incomes could not only enhance food security, but also enhance involvement in the formal seed system among resource-poor communities.

The need to expand research on informal seed systems, however, goes beyond concerns about informal and formal seed system linkages, to bigger debates about the contribution of informal seed systems to local, regional, and global food security. Of particular import is that informal seed systems lie at the nexus of food sovereignty and food security debates. This case study has highlighted the value of informal seed systems toward enhancing food security, but food sovereignty concerns in such seed systems are also critically important, especially as they can uncover subtle dynamics of these seed systems that can influence food security outcomes. The importance of seed to the food sovereignty of households includes both (1) who gets to decide which seeds to plant, when, and where, and (2) how intra- and inter-household and community inequalities affect this decision-making process. Although some argue that food security 
and food sovereignty are competing paradigms (Boyer, 2010; Schanbacher, 2010; Wittman, 2011), there is also a growing literature positing that these paradigms can co-exist (Lee, 2007). This has been highlighted by the recent push to finally acknowledge Via Campesina's (1996) stated position that food sovereignty is a necessary precondition for food security. In 2010, the FAO revised its definition of food security to incorporate elements of food sovereignty, stating that, "The right to adequate food is a fundamental human right and must be safeguarded, particularly for the most vulnerable" (FAO, 2010, p. 9). Furthermore, Menezes (2001) and Rosset (2011) have posited that enhancing food security to tackle global hunger cannot be successful without first taking the food sovereignty step, that is, communities cannot be truly food secure and free from hunger concerns unless they have some say about where their food comes from and how it is produced. The role of informal seed systems in providing such a food sovereignty step toward more food-secure futures is worth further investigation.

\section{Conclusion}

This study outlined a broad spectrum of approaches to strengthen informal seed systems in resource-poor rural communities in Southeast Asia. Much of the work undertaken provided a baseline of informal seed system understanding in the three communities of study. Although this project either directly or potentially enhanced all four pillars of food security in each community, it succeeded only in laying the foundation upon which future approaches to informal seed system strengthening could be built. Future studies to assess these communities' level of continued involvement in informal seed systems would be useful in further understanding the success of these strengthening approaches. Furthermore, expanding informal seed systems research into other geographic locations and integrating informal seed systems considerations into wider debates are both critical for the continued preservation and optimum utilization of important genetic resources in a rapidly changing world.

\section{Acknowledgements}

The authors would like to express their thanks to the community clusters of rural Chiang Dao (Chiang Mai) and Mae Yao (Chiang Rai), Thailand, and Svay Rieng, Cambodia, for allowing us to work alongside you and understand your seed and agroecological systems. Many thanks also must go to the generous support of USAID's Horticulture Collaborative Research Support Program, managed by the University of California, Davis, for the funding of this research, and also to Maejo University for its collaborative partnership.

\section{References}

Almekinders, C. J. M., Louwaars, N. P., \& de Bruijn, G. H. (1994). Local seed systems and their importance for an improved seed supply in developing countries. Euphytica, 78, 207-216. http://dx.doi.org/10.1007/BF00027519

Annan, K. (2004, July 6). Secretary-General calls for "uniquely African Green Revolution" in $21^{\text {st }}$ century to end continent's plague of hunger, in Addis Ababa remarks (United Nations Press Release SG/SM/9405, AFR/988, 2004). Available from: http://www.un.org/News/Press/docs/ 2004/sgsm9405.doc.htm

Badstue, L. B., Bellon, M. R., Berthaud, J., Juárez, X., Rosas, I. M., Solano, A. M., \& Ramírez, A. (2006). Examining the role of collective action in an informal seed system: A case study from the Central Valleys of Oaxaca, Mexico. Human Ecology, 34(2), 249-273. http://dx.doi.org/10.1007/s10745006-9016-2

Bicksler, A., Bates, R., Burnette, R., Gill, T., Meitzner Yoder, L., Ricciardi, V., \& Srigiofun, Y. (2012). Methodologies for strengthening informal indigenous vegetable seed systems in northern Thailand and Cambodia. Acta Horticulturae (ISHS) 958, 67-74. http://www.actahort.org/books/958/958 6.htm

Boyer, J. (2010). Food security, food sovereignty and local challenges for transnational agrarian movements: The Honduras case. The Journal of Peasant Studies, 37(2), 319-351. http://dx.doi.org/10.1080/03066151003594997

Engle, L. M., \& Faustino, F. C. (2007). Conserving the indigenous vegetable germplasm of Southeast Asia. Acta Horticulturae, 752, 55-60. 
Food and Agriculture Organization of the United

Nations [FAO]. (2008). An introduction to the basic

concepts of food security. Retrieved from

http://www.fao.org/docrep/013/al936e/

al936e00.pdf

FAO. (2010). FAO policy on indigenous and tribal peoples.

Rome: Author. Available from

http://www.fao.org/

FAO. (2011). The state of food insecurity in the world. Rome: Author.

Gajaseni, J., \& Gajaseni, N. (1999). Ecological rationalities of the traditional homegarden system in the Chao Phraya Basin, Thailand. Agroforestry Systems, 46, 3-23. http://dx.doi.org/10.1023/A:1006188504677

Government of the Kingdom of Thailand. (2011). Chiang Rai Province official site. Retrieved from http://www.chiangrai.go.th/cpoc/2011/ Default.aspx

Government of the Kingdom of Thailand. (2012). Chiang Mai Province official site. Retrieved from http://www.chiangmai.go.th/newweb/main/ index.php

Jackson, L. E., Pascual, U., \& Hodgkin, T. (2007). Utilizing and conserving agrobiodiversity in agricultural landscapes. Agriculture, Ecosystems and Environment, 121(3), 196-210. http://dx.doi.org/10.1016/j.agee.2006.12.017

Kehlenbeck, K., \& Maass, B. L. (2004). Crop diversity and classification of homegardens in Central Sulawesi, Indonesia. Agroforestry Systems, 63(1), 5362. http://dx.doi.org/10.1023/B:AGFO. $\underline{0000049433.95038 .25}$

Kingdom of Cambodia (2009). Svay Rieng Data Book. Retrieved from http://www.ncdd.gov.kh/images/ stories/ncdd/2010/pdb/eng/ProvDataBook_E_ 20 2008.pdf

Kumar, B. M., \& Nair, P. K. (2004). The enigma of tropical homegardens. Agroforestry, 61, 135-152. http://dx.doi.org/10.1023/B:AGFO.0000028995. $\underline{13227 . \mathrm{ca}}$

Lee, R. (2007). Food security and food sovereignty (Centre for Rural Economy Discussion Series Paper Series No. 11). Newcastle Upon Tyne, UK: University of Newcastle Upon Tyne.

Mayes, S., Massawe, F. J., Alderson, P. G., Roberts, J. A., Azam-Ali, S. N., \& Hermann, M. (2012). The potential for underutilized crops to improve security of food production. Journal of Experimental Botany, 63(3), 1075-1079. http://dx.doi.org/10.1093/jxb/err396

McGuire, S. (2008). Securing access to seed: Social relations and sorghum seed exchange in eastern Ethiopia. Human Ecology, 36, 217-229.

Menezes, F. (2001). Food sovereignty: A vital requirement for food security in the context of globalization. Development, 44(4), 29-33. http://dx.doi.org/10.1057/palgrave.development. $\underline{1110288}$

Myers, N., Mittermeier, R. A., Mittermeier, C. G., da Fonseca, G. A. B., \& Kent, J. (2000). Biodiversity hotspots for conservation priorities. Nature, 403, 853-858. http://dx.doi.org/10.1038/35002501

Nabhan, G. (2009). Where our food comes from: V avilov's quest to end famine. Washington, D.C.: Island Press.

Rao, N. K., Hanson, J., Dulloo, M. E., Ghosh, K., Nowell, D., \& Larinde, M. (2006). Handbook 8: Manual of seed handling in genebanks. Rome: Biodiversity International.

Rosset, P. (2011). Food sovereignty and alternative paradigms to confront land grabbing and the food and climate crises. Development, 54(1), 21-30. http://dx.doi.org/10.1057/dev.2010.102

Schanbacher, W. D. (2010). The politics of food: The global conflict between food security and food sovereignty. Santa Barbara, California: Praeger.

Scoones, I., \& Thompson, J. (2011). The politics of seed in Africa's Green Revolution: Alternative narratives and competing pathways. IDS Bulletin, 42(4), 1-23. http://dx.doi.org/10.1111/j.1759-5436.2011. 00232.x

Seboka, B., \& Deressa, A. (1999). Validating farmers' indigenous social networks for local seed supply in central rift valley of Ethiopia. Journal of Agricultural Education and Extension, 6(4), 245-254. http://dx.doi.org/10.1080/13892240085300071

Sperling, L. (2008). When disaster strikes: A guide to assessing seed system security. Cali, Colombia: International Center for Tropical Agriculture (CIAT).

Sperling, L., \& McGuire, S. (2010). Understanding and strengthening informal seed markets. Experimental Agriculture, 46(2), 119-136. http://dx.doi.org/10.1017/S0014479709991074 
Srithi, K., Trisonthi, C., Wangpakapattanawong, P., Srisanga, P., \& Balslev, H. (2012). Plant diversity in Hmong and Mien homegardens in northern Thailand. Economic Botany, 66(2), 192-206. http://dx.doi.org/10.1007/s12231-012-9199-y

Thiele, G. (1999). Informal potato seed systems in the Andes: Why are they important and what should we do with them? World Development 27(1), 83-99. http://dx.doi.org/10.1016/S0305-750X(98) 00128-4

Thrupp, L. A. (2000). Linking agricultural biodiversity and food security: The valuable role of sustainable agriculture. International Affairs, 76(2), 265-281. http://dx.doi.org/10.1111/1468-2346.00133

Tscharntke, T., Clough, Y., Wanger, T. C., Jackson, L., Motzke, I., Perfecto, I., Vandermeer, J., \& Whitbread, A. (2012). Global food security, biodiversity conservation and the future of agricultural intensification. Biological Conservation,
151(1), 53-59. http://dx.doi.org/10.1016/ j.biocon.2012.01.068

United Nations. (2003). Trade reforms and food security. Retrieved from http://www.fao.org/docrep/005/ $\mathrm{y} 4671 \mathrm{e} / \mathrm{y} 4671 \mathrm{e} 06 . \mathrm{htm}$

United States Treasury (2011, March 1). Remarks by Assistant Secretary Marisa Lago to the Partnership to End Hunger and Poverty in Africa's Annual Forum. Retrieved from http://www.treasury.gov/ press-center/press-releases/Pages/tg1083.aspx

Via Campesina. (1996). The right to produce and access to land: Food sovereignty: A future without hunger. Rome: Author. Retrieved from: http://www.voiceoftheturtle.org/ library $/ 1996 \% 20$ Declaration $\% 20$ of $\% 20$ Food $\% 20$ Sovereignty.pdf

Wittman, H. (2011). Food sovereignty: A new rights framework for food and nature? Environment and Society: Advances in Research, 2, 87-105. http://dx.doi.org/10.3167/ares.2011.020106 